\title{
Time running out for the last US fast breeder reactor
}

Idaho Falls, Idaho. Managers responsible for the operation of the only fast breeder nuclear reactor left in the United States are trying to persuade the Clinton administration to shelve plans to close it down next month. They argue that the reactor should stay critical for a further 3-5 years to support an associated experiment in actinide recycling.

The survival of the Integral Fast Reactor (IFR) in Idaho would represent a setback for environmentalists, who persuaded President ter as part of his budget proposals for the fiscal year 1994. Clinton made the promise on the basis that the fast reactor was not close to commercial application and that the money saved by closing it could be quickly transferred into renewable energy research. The Integral Fast Reactor programme, as its name implies, seeks to integrate an existing fast reactor with a compact fuel recycling process.

The Department of Energy (DoE) is now negotiating with both the administration's Office of Management and Budget and possible Japanese backers about ways of keeping the programme alive. It is expected to file revised budget proposals to Congress for the IFR, which is located at the department's Argonne West laboratory.

Under the original budget proposal for the IFR for next year, $\$ 60$ million was to be spent on closing down the reactor, and a further $\$ 15$ million on continuing an experiment in recycling its fuel. The revised proBill Clinton to promise its closure last win-

posal will acknowledge that closure would cost around $\$ 100$ million during the 1994 fiscal year, which begins on 1 October.

According to IFR managers, the DoE now believes it would be better to keep the reactor running, as that would simplify and strengthen the recycling experiment without much additional cost. John Sackett, director of IFR operations at Argonne West, says that a phased shutdown of the reactor over five years, combined with a full demonstration of the associated recycling process, would cost $\$ 440$ million.

This compares with a cost of $\$ 400$ million over the same period if the reactor was closed next month. Under the DoE's original proposal - widely criticized as impractical - irradiated fuel from foreign fast reactors would be shipped to and from Argonne West for experimental reprocessing (see Nature 362, 683; 1993).

It is not clear whether the administration's budget amendment will specify a closure date for the sodium-cooled, metal fuel reactor at Argonne West. A spokeswomen for the energy department said that it could not comment on budget negotiations. But the amendment will probably just raise the request to around $\$ 100$ million, and leave Congress to decide if it wants to order the reactor's shutdown.

The House of Representatives has already voted for such a shutdown, stripping out the $\$ 15$ million actinide recycling programme as well (see Nature 364, 6; 1993). But the Senate energy and water appropria-

\section{Reprieve for Canadian research}

Ottawa. Mrs. Kim Campbell, the Canadian Prime Minister, has reversed a decision announced by the federal government last month that would have virtually halved the funding of a research programme launched in 1989 to increase the country's international competitiveness.

Campbell, whose conservative government is about to face a federal election, was reacting to a wave of protest from both the research and industrial community that had greeted a decision to cut funds for its Networks of Centres of Excellence (NCE) programme from $\mathrm{C} \$ 60$ million to $\mathrm{C} \$ 30$ million a year (see Nature 364, 566; 1993).

Addressing a meeting of the Rotary Club of Toronto, Campbell said that both she and the Minister for Science and Small Business had listened closely to criticism of the decision. As a result, she said, funding for the programme will be maintained at C $\$ 48$ mil- lion a year for each of the next four years.

The NCE programme currently supports about 800 research workers, as well as almost 2,000 graduate students and postdoctoral fellows, and covers fields ranging from biotechnology to robotics. Campbell said that restoring the funds that were to have been cut "will be done within existing resource levels and without affecting the funding of other science and technology activities of the government".

But she also criticized that low level of industrial contribution to the programme, describing the C $\$ 4$ million that the private sector has provided so far as "paltry" and unacceptable. Campbell repeated previous calls that business and industry should join the government in both in becoming partners in funding research and development and in reducing the national deficit.

David Spurgeon

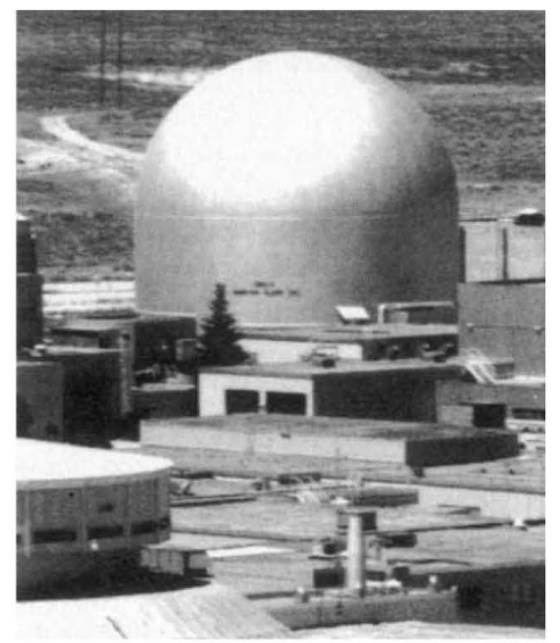

IFR: another reprieve?

tions subcommittee is likely to support the continuation of the IFR programme when it considers the budget later this month, and this is likely to be approved by the full Senate.

IFR's fate will then depend on the outcome of a conference between the House and Senate. As with the Superconducting Super Collider - whose fate is likely to rest with same conference - supporters of the IFR can draw comfort from the fact that the make-up of the conference will reflect the conservative, pro-nuclear bias of the Senate.

At Argonne West, engineers are installing the purpose-built equipment which would recycle fuel from the 29-year-old experimental fast reactor (EBR 2) next door. The equipment would strip and process metal fuel rods by hydrolysis under remote control inside a chamber - built in the 1960 s to accommodate a previous, long-since abandoned reprocessing scheme - surrounded by five-foot-thick concrete and glass walls.

Sackett and his team argue that most of the world's fast breeder reactor programmes took a wrong turning in the 1960 s when they pursued oxide-based fuels, which do not breed well and are complicated to reprocess. The EBR 2 uses metal fuel, and the associated recycling process is far simpler than the complex chemical plant needed to reprocess oxide-based nuclear fuels.

The IFR's end-products would include plutonium mixed with other actinide elements and therefore unusable in bomb-making, they say. But the radiation inside the chamber will be so intense that electric motors used to activate equipment, for example, will last only a few months.

Japanese electricity generators have pledged $\$ 43$ million towards the Integrated Fast Reactor programme for the period 1991-96. The DoE is now seeking a further $\$ 60$ million over four years from Japan to help keep the programme going. But no agreement is expected before Congress decides on the IFR's future. Colin Macilwain 